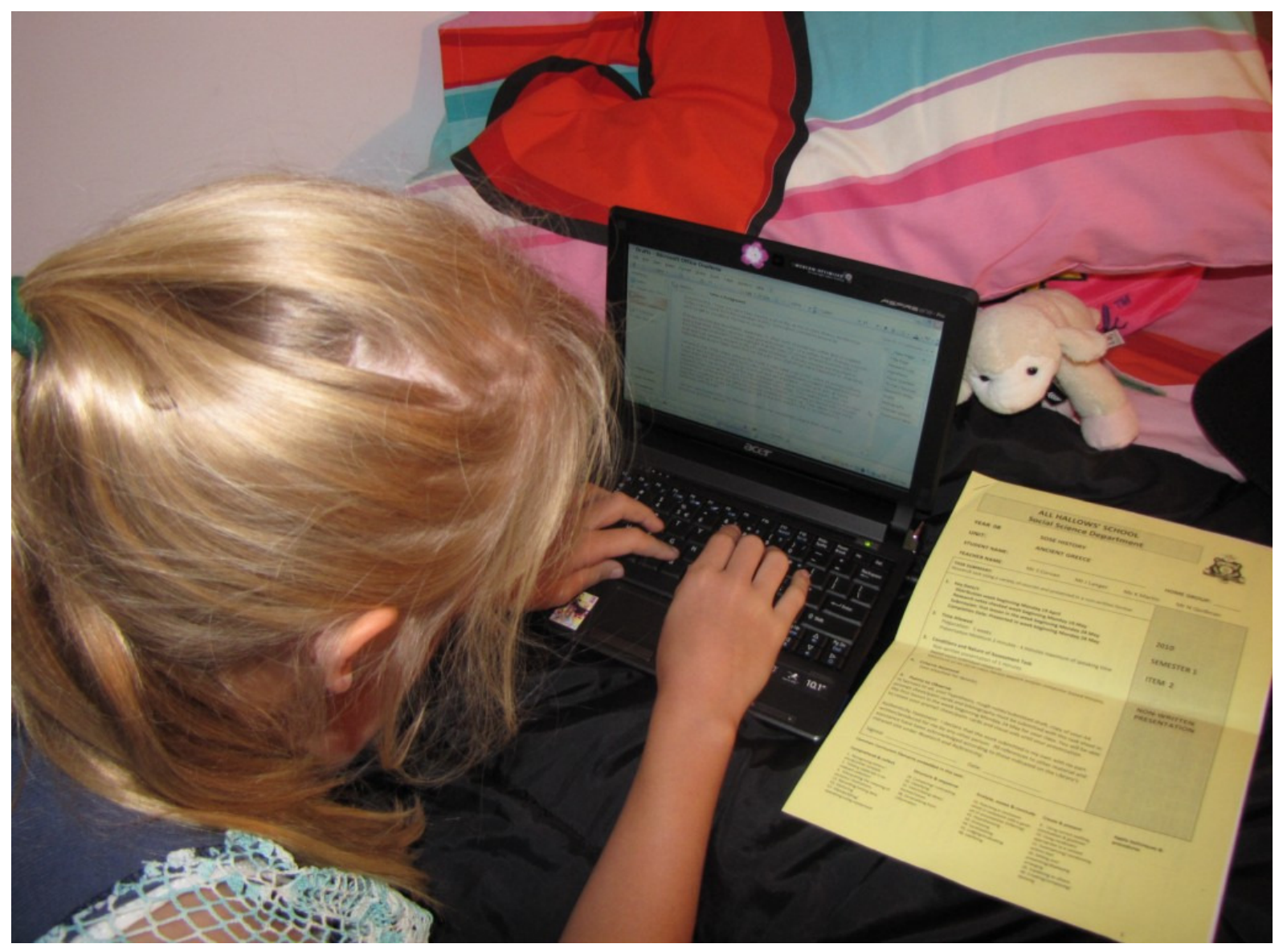

(Weaver, 2010)

\title{
Personal, portable, multifunction-devices and school libraries
}

\author{
Anne Weaver
}

Email anneweaver9@gmail.com

Blog http://readingpower.wordpress.com/

(C) 2010 IASL, SLAQ and therein by the authors. Diversity Challenge Resilience: School Libraries in Action Proceedings of the $12^{\text {th }}$ Biennial School Library Association of Queensland, the $39^{\text {th }}$ International Association of School Librarianship Annual Conference incorporating the $14^{\text {th }}$ International Forum on Research in School Librarianship, Brisbane QLD Australia, 27 September - 1 October 2010. 


\title{
Personal, portable, multifunction-devices and school libraries
}

\author{
Anne Weaver \\ Email anneweaver9@gmail.com Blog http://readingpower.wordpress.com/
}

\begin{abstract}
To maximise learning value from one-to-one programs in schools, computing devices need to be personal, portable and multifunctional. It is likely that shared devices will not be as effective. The increased access provided by one-to-one devices creates great opportunities for school librarians to support their school technology directions and to implement $21^{\text {st }}$ century information literacy and reading promotion programs. Increased access will mean greater utilisation and demand for online resources. The key factor in the success of one-to-one programs is teacher implementation of appropriate pedagogies. Teacher-librarians have the chance to provide leadership in pedagogies that most effectively utilise these devices to improve learning outcomes.
\end{abstract}

If we consider how ipods have revolutionised the music industry, what are the implications of personal, portable, multifunction-devices (PPMs) for learning and school libraries? Increasingly, the anecdotal and research experience is that learning needs to be continuous, not discontinuous and a personal part of a student's learning life. If a teacher has to book a computer lab or book a laptop trolley, there is discontinuity - learning stops and starts, and there is no ongoing personal relationship with the learning device. Computing devices need to be integrally blended into learning, both inside and outside the classroom.

Learning can benefit from the example of the mobile phone, one of the most successful information and communication technologies of the last 30 years - mobile phones are personal, portable, and multifunction; and today have wireless web access. Such learning devices need to meet the majority of a student's daily learning needs, such as:

- $\quad$ word processing

- printing

- information retrieval (searching, textbooks, accessing school learning management system),

- video, camera and sound recording,

- communication (email, collaboration),

- tools - software,

- connection to their learning networks (moodle, online textbooks),

- access at home and school and elsewhere (wireless), and

- can be personally adapted to the student

Learning theorists from Dewey to Vygotsky to Seely Brown see learning as a personal process in a social context. Personalisation makes learning flexible, adaptive and student centred. Learners become co-producers. Personalisation of learning devices also comes from their size, connectivity and "belonging" to the user (State Govt. of Victoria, 2009). Thus, a ratio of one-to-one computers may be insufficient to improve learning outcomes. Students and staff need to have their 'own' personal, portable multifunction-device. For school libraries this means an opportunity to attain an increasingly important role as their school communities' gain increased access to information, with all its associated implications and challenges.

C 2010 IASL, SLAQ and therein by the authors. Diversity Challenge Resilience: School Libraries in Action Proceedings of the $12^{\text {th }}$ Biennial School Library Association of Queensland, the $39^{\text {th }}$ International Association of School Librarianship Annual Conference incorporating the $14^{\text {th }}$ International Forum on Research in School Librarianship, Brisbane QLD Australia, 27 September - 1 October 2010. 


\section{General context}

The research about one-to-one programs is limited, often does not apply sufficient criteria, and is not omnipotent; decisions in education are often based on other criteria. Students and teachers are demanding increased access to computer resources. Computer labs cost hundreds of thousands of dollars. Netbooks cost from $\$ 500$ per student and these costs may be defrayed by technology levees. Shared laptops are discontinuous with students needing multiple places to store information ranging from paper to USB. In addition, using computer labs or booking laptops means use has to be planned ahead, reducing 'just in time' learning.

Personal and portable computing devices can be taken many places, including home. This extends the effectiveness of the eLearning environment. In one study, 50 percent of Internet access to Intel school eLearning content was after school (Intel, 2009).

The full opportunities for using PPMs to increase academic performance are still being investigated. It is difficult to isolate the effect of PPMs. However, in a well known study, the State of Maine implemented a oneto-one laptop program for all $7^{\text {th }}$ and $8^{\text {th }}$ grade students and teachers. Five years after the initial implementation of the laptops, student writing scores had significantly improved. Students scored better the more extensively they used their laptops in developing and producing their writing. Using laptops helped students to improve their writing in general, not only when using laptops (Silvernail and Gritter, 2008). A longitudinal study of four elementary schools in Israel found that using computers improved learning. However, they found laptops alone are not sufficient to increase learning outcomes. There must also be appropriate learning goals, curricula, teaching strategies, and assessments (Spektor-Levy et al, 2009). Other research is summarised in the following table (Bielefeldt, 2006).

Table 1. Reported advantages of laptop and handheld computing. (Bielefeldt, 2006)

\begin{tabular}{|l|l|l|}
\hline \multicolumn{1}{|l|}{$\begin{array}{l}\text { Attendance and discipline rates } \\
\text { improve. }\end{array}$} & $\begin{array}{l}\text { Knezek \& Christensen, (2005); } \\
\text { Light et al. (2002); Zucker \& } \\
\text { McGhee, (2005) }\end{array}$ & $\begin{array}{l}\text { Discipline referrals in Texas schools } \\
\text { participating in a laptop initiative dropped, } \\
\text { while referral rates in comparison schools } \\
\text { increased. (Knezek \& Christensen, 2005) }\end{array}$ \\
\hline $\begin{array}{l}\text { Students access a broader array } \\
\text { of learning resources and } \\
\text { experiences (including increased } \\
\text { collaboration with others and } \\
\text { increased use of technology for } \\
\text { learning). }\end{array}$ & $\begin{array}{l}\text { Lane (2003); Light, et al. } \\
\text { (2002); Vahey \& Crawford } \\
\text { (2002); Walker et al. (2000); } \\
\text { Zucker \& McGhee, (2005) }\end{array}$ & $\begin{array}{l}\text { Increased use of technology for educational } \\
\text { use in school and at home; improved scores } \\
\text { on writing assessment in the } \\
\text { Microsoft/Toshiba Learning Anytime } \\
\text { Anywhere Pilot (Walker et al., 2000). }\end{array}$ \\
\hline $\begin{array}{l}\text { Relationship between teacher } \\
\text { and student changes }\end{array}$ & $\begin{array}{l}\text { Bobkoff \& Kratcoski, (2004- } \\
\text { 2005); Honey (2001); Sargent } \\
\text { (2003); Light et al. (2002). } \\
\text { Owen et al. (2005-2006); } \\
\text { Zucker \& McGhee, (2005) }\end{array}$ & $\begin{array}{l}\text { Students and teachers report increased } \\
\text { frequency and quality of supportive } \\
\text { individual and group interactions (Light et } \\
\text { al., 2000). }\end{array}$ \\
\hline $\begin{array}{l}\text { Student attitudes toward school } \\
\text { improve. }\end{array}$ & $\begin{array}{l}\text { Lane 2003; Vahey \& Crawford, } \\
\text { (2002); Swan et al. (2005); } \\
\text { Zucker \& McGhee, (2005) }\end{array}$ & $\begin{array}{l}\text { Students and teacher survey responses show } \\
\text { increased enthusiasm for school work in } \\
\text { classes among participants in Palm's } \\
\text { Education Pioneers program (Vahey \& } \\
\text { Crawford, 2002). }\end{array}$ \\
\hline $\begin{array}{l}\text { Parent attitudes toward school } \\
\text { improve. }\end{array}$ & $\begin{array}{l}\text { Rockman (2003); Zucker \& } \\
\text { McGhee, (2005). }\end{array}$ & $\begin{array}{l}\text { In schools participating in laptop programs, } \\
\text { parent involvement and communication } \\
\text { increases (Rockman, 2003). }\end{array}$ \\
\hline
\end{tabular}

(C) 2010 IASL, SLAQ and therein by the authors. Diversity Challenge Resilience: School Libraries in Action Proceedings of the $12^{\text {th }}$ Biennial School Library Association of Queensland, the $39^{\text {th }}$ International Association of School Librarianship Annual Conference incorporating the $14^{\text {th }}$ International Forum on Research in School Librarianship, Brisbane QLD Australia, 27 September - 1 October 2010. 


\begin{tabular}{|l|l|l|}
\hline Student achievement increases. & $\begin{array}{l}\text { Gulek \& Demirtas, (2005); } \\
\text { Light et al. (2002); Muir et al. } \\
\text { (2004); Swan et al. (2005); } \\
\text { Walker et al. (2000). }\end{array}$ & $\begin{array}{l}\text { Schools implementing Maine's laptop } \\
\text { initiative for three years had significantly } \\
\text { higher test scores than comparison schools } \\
\text { in Science, Math, and Visual/Performing } \\
\text { arts. (Muir et al., 2004). }\end{array}$ \\
\hline
\end{tabular}

Andrew Zucker stated, "Change is a process, not a purchase. Teachers have to change the way that they conduct instruction and their expectations of the way students will learn" (Zucker and Light, 2009). A study of four oneto-one computing projects in K-12 schools identified key success factors as adequate planning, stakeholder buyin and strong school or district leadership. However, researchers said the most important factor of all is teaching practices. Laptop programs are only as effective as the teachers who apply them (Centre for Digital Education, 2008; Stansbury, 2010). Learning needs to become student rather than teacher centred. Teachers need highquality professional development to learn the best methods to teach effectively with one-to-one PPMs (Ash, 2010). The diagram below considers the factors needed to increase the value of technology programs.

\section{Progression of eLearning Environments}

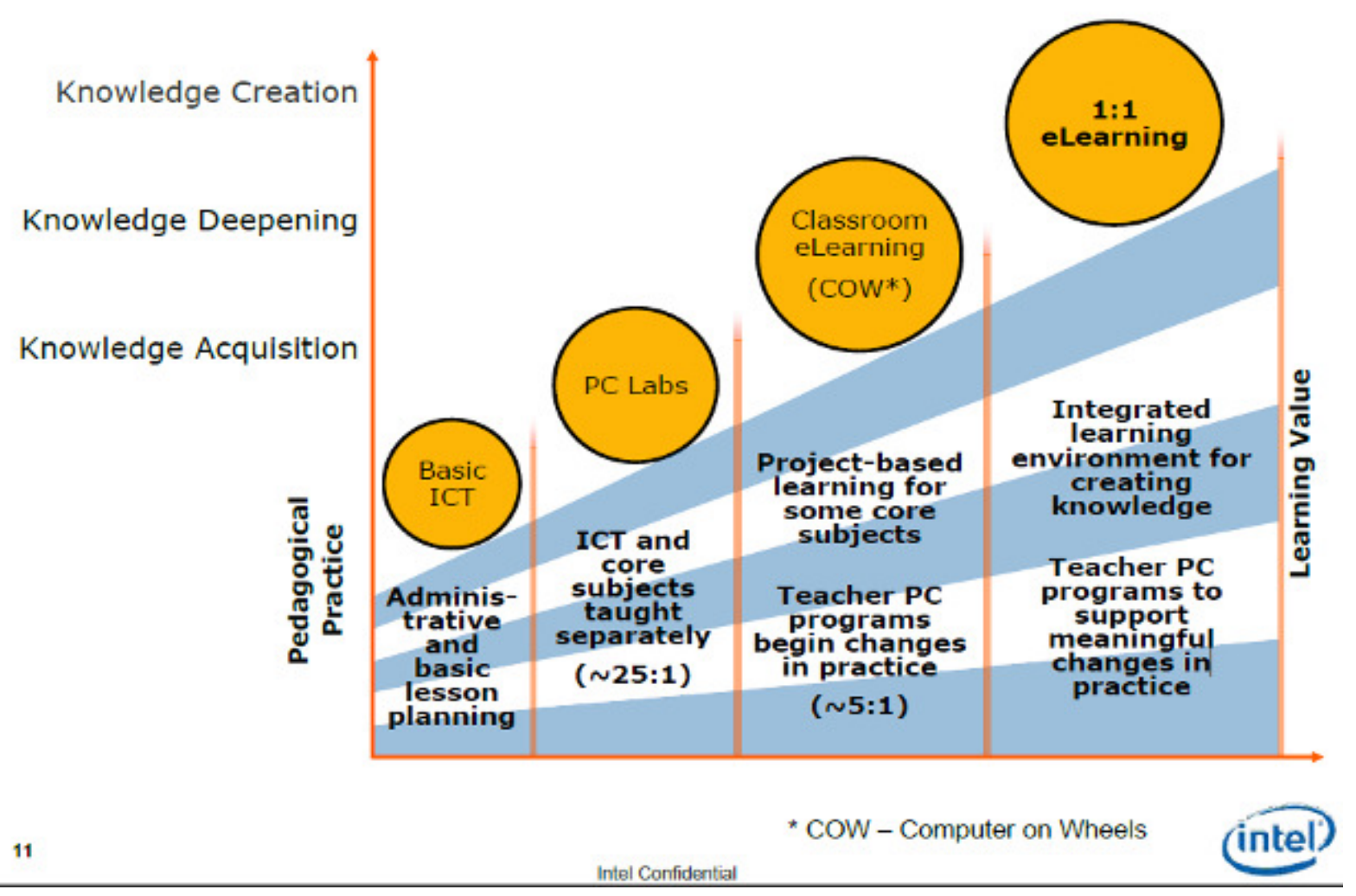

Figure 1 Progression of eLearning Environments (Fogel, 2010)

PPM access has been found to increase teacher productivity. Studies indicate that teachers creating lesson plans using digital resources saved an average of 26 minutes compared to those who did not, and teachers felt quality was higher. Teachers also found one-to-one programs had a host of other benefits (Intel, 2009; Centre for Digital Education, 2008).

(C) 2010 IASL, SLAQ and therein by the authors. Diversity Challenge Resilience: School Libraries in Action Proceedings of the $12^{\text {th }}$ Biennial School Library Association of Queensland, the $39^{\text {th }}$ International Association of School Librarianship Annual Conference incorporating the $14^{\text {th }}$ International Forum on Research in School Librarianship, Brisbane QLD Australia, 27 September - 1 October 2010. 
PPMs increase opportunities for online learning courses. An analysis of online learning research by the U.S. Department of Education showed that students who took all or part of classes online performed better, on average, than those taking the same course through traditional face-to-face instruction. They found that more than 40 percent of $6^{\text {th }}$ through $12^{\text {th }}$ graders showed interest in taking online courses, but only 10 percent have actually studied one at school. Seven percent of middle school students and four percent of high school students pursued opportunities outside school to take online courses (eschoolnews.com, 2009).

Some critics of distance learning say face-to-face classes are more effective, but an Indiana University study found that online learners reported deeper approaches to learning than classroom-based learners (Prabhu, 2008). 'Hybrid courses', that deliver part of their instruction in a traditional lecture manner and part in an online environment, are increasingly popular. Research at the University of Houston's Laboratory of Integrated Physiology, found that final student grades were 9.9 percent higher (an increase of one letter grade on a standard grading scale) when the course was presented in a hybrid format (Stansbury, 2008). Online learning courses are just one of the many educational options facilitated by increased computer access.

Efforts to measure the effectiveness of laptop or netbook programs for student learning often fail to consider the negative effects of lack of computer access. How much additional time do students take to complete tasks when they handwrite at school, and then must type the information into a computer at home? How much time is taken copying from the black or whiteboard or finding that lost USB? Then, there is the whole potential for other benefits such as paperless learning, and improved administration and statistical analysis to inform learning. The curriculum keeps expanding, but how can this be achieved, if learning efficiencies are not created?

\section{Specific context}

So within this worldwide context, All Hallows' School currently has approximately 800 wireless netbooks allocated to staff and secondary students. This will increase to over 1300 netbooks by January 2011 when the secondary rollout is completed. All Hallows' is a Catholic school of 1400 girls from years 5 to 12 (ages 10 to 17). In addition, trials are planned this year for using netbooks with Years 5-7.

In 2007, the school had six computer labs, seven half computer labs, 80 desktop computers in the libraries, 35 laptops and 15 eeePCs, numerous PDAs, and an array of staff computers, but demand was still exceeding supply. With competition for bookings, students were able to access the computers for less than two lessons per day. The cost of building computer labs was soaring. The students with PDAs still needed to use computer labs for many activities. The shared laptop devices were slow in logging on, which resulted in limitations to the number of devices that could be used at once. Lending laptops was very time consuming for library staff. In 2008, the school decided netbooks offered a cost-effective solution to the demand for increased access. In 2009, about 300 Acer Aspire netbooks were issued to Year 10 students and teachers (Pembroke, 2009).

Year 10 students were surveyed in mid 2009 through an online moodle questionnaire. Nearly 40 percent of students used the netbooks in four or more lessons per day, while 31 percent of students used their netbooks for two to three additional hours after returning home at night. Many students connect netbooks to their home internet and utilize free wireless networks available on trains and other venues (Pembroke, 2009).

Seventy percent of students were satisfied with the size of the device. The most widely used application is Microsoft Word followed by Microsoft OneNote. Other popular uses include viewing electronic textbooks, Microsoft Excel, accessing moodle, and Internet research. The computer labs are still bookable for high end

(C) 2010 IASL, SLAQ and therein by the authors. Diversity Challenge Resilience: School Libraries in Action Proceedings of the $12^{\text {th }}$ Biennial School Library Association of Queensland, the $39^{\text {th }}$ International Association of School Librarianship Annual Conference incorporating the $14^{\text {th }}$ International Forum on Research in School Librarianship, Brisbane QLD Australia, 27 September - 1 October 2010. 
computer work, but most learning can be managed by netbooks. However, usage has continued to escalate and new servers and increased wireless points have now been provided (Pembroke, 2009).

Protective carry cases have been provided for netbooks. If there is a problem with a netbook, the SD card can be swapped to a "loan" netbook, until it is fixed. A product called SynchronEyes is used so teachers can manage what students are accessing on netbooks. Students can print from their netbooks to a variety of devices in the school libraries and one of the computer labs.

Dunleavy, Dexter and Heinecke (2007) state it is critical to implement procedures that allow teachers to focus on the significant tasks of integration, rather than distracting management issues such as charging the laptops' batteries or preventing students from accessing inappropriate Internet sites. Our library supports this by providing 'swap and go' batteries, printing services, basic troubleshooting and generally supporting school technology use. This enhances the library's role as integral to the learning process at our school.

All Hallows' uses a Blended Learning model. This is defined as "blending of different learning methods, techniques and resources and applying them in an interactively meaningful learning environment" (Wikipedia, 2010). All staff with netbooks have attended school-based professional learning about using netbooks. Each subject department has established goals in terms of developing digital lessons. Each department has been allocated a teacher with the role of Blended Learning Mentor to support blended learning. In addition, professional learning from external sources has been provided, such as Jamie McKenzie's presentation on managing the laptop classroom, and designing digital lessons to maximise learning outcomes (McKenzie, 2008.) All classrooms have interactive whiteboards, and moodle is well developed as the online management system. The school provides in-house professional learning sessions in technology throughout the year.

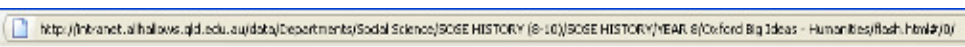

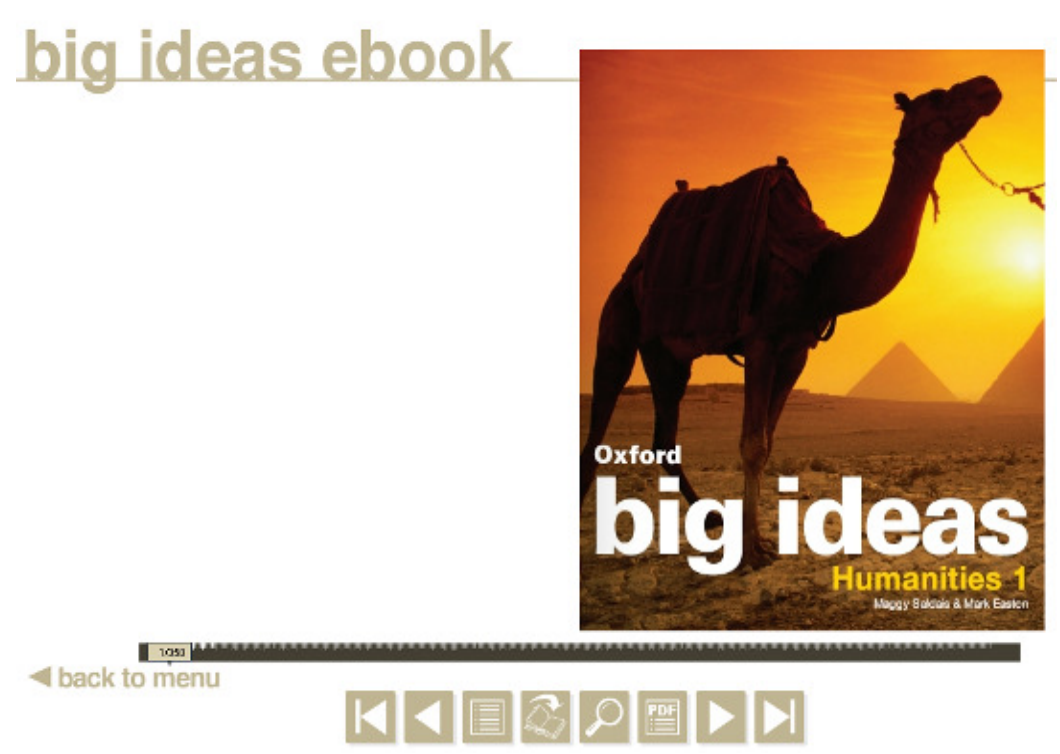

\section{E textbooks}

Another advantage of netbooks is that they promote access to online books, including textbooks such as the one in Figure 2 (Saldais and Easton, 2008). Similarly, personal devices allow literature to be accessed online, such as short stories from the Ziptales subscription website (Ziptales, 2007). This is an online collection of short stories for primary and lower secondary students that are graded for readability. These and other library databases can be accessed more easily by students when students have their own computing devices.

Figure 2 Big ideas ebook (screen image see Saldais and Easton, 2008)

\section{The impact on school libraries}

Netbooks have greatly facilitated teaching of information literacy skills. Learning can be 'hands on', rather than (C) 2010 IASL, SLAQ and therein by the authors. Diversity Challenge Resilience: School Libraries in Action Proceedings of the $12^{\text {th }}$ Biennial School Library Association of Queensland, the $39^{\text {th }}$ International Association of School Librarianship Annual Conference incorporating the $14^{\text {th }}$ International Forum on Research in School Librarianship, Brisbane QLD Australia, 27 September - 1 October 2010. 
lectures and thus is more effective. Booking computer labs was time consuming and availability was often an issue. With their own device, students have improved access to the library moodle resources and catalogue. Also when researching, students do not have discontinuous learning where in some lessons they might be taking notes with pens, and then have to retype work later. Having their own personal mobile device creates a seamless learning context, and reduces information transfer problems. Students develop a continuous learning process centred on their netbook.

Video content is accessible via the netbooks. Teachers can prepare worksheets and activities related to video resources and students can work on these at their own pace. In relation to the reading program, students now have greater access to author sites and online reading materials. Email can be used more extensively to communicate information to students. Students with netbooks are more responsive to overdue notices which are emailed.

\section{Netbooks and the library website}

The activities of school libraries will be more effective if based on evidence. The analytical tools and interactive activities in moodle are very useful, and these can be used more extensively when students have computer access. Questionnaires can be easily and quickly compiled for students to complete online. Moodle produces useful analysis as seen in the next image. The results from our online reading questionnaire have been very useful to identify individual students who need more reading support, and to highlight the role of library staff in helping students find books to read. In addition, there are many interactive and online learning activities that can be used for teaching information literacy when computer access is available (Weaver, 2010).

\begin{tabular}{|c|c|c|}
\hline \multicolumn{3}{|l|}{ Ilove readirg. } \\
\hline Response & Average & Total \\
\hline Yes & $94 \%$ & 67 \\
\hline No & $6 \%$ & 4 \\
\hline Total & $100 \%$ & $71 \pi 1$ \\
\hline \multicolumn{3}{|c|}{ 10. Ihave trouble finding a good book. } \\
\hline Response & Average & Total \\
\hline Yes & $=42 \%$ & 30 \\
\hline No & 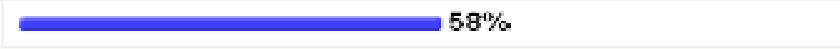 & 41 \\
\hline Total & 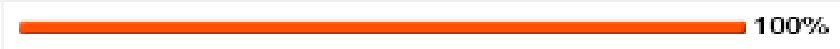 & 7171 \\
\hline \multicolumn{3}{|c|}{ 11. Im too busy to read during the school tem. } \\
\hline Response & Average & Total \\
\hline Yes & $8 \%$ & 6 \\
\hline No & $=$ & 66 \\
\hline Total & 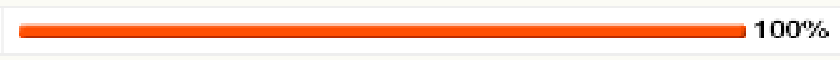 & 7171 \\
\hline \multicolumn{3}{|c|}{ 12. lprefer to read magazines instead of books. } \\
\hline Response & Average & Total \\
\hline Yes & $7 \%$ & 5 \\
\hline No & 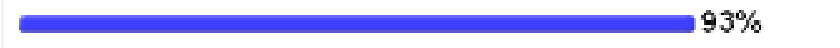 & 66 \\
\hline
\end{tabular}


Figure 3 Moodle questionnaire (All Hallows' School 2010)

Reports were obtained from the library management system to determine if the increased number of netbooks impacted on borrowing of books. Overall borrowing for Year 8 was only slightly higher in 2010, than 2009, but there may have been a novelty factor impact, as Year 8s were issued their netbooks at the end of week 1 , Term 2. However, borrowing for Years 9-12 was 30\% higher in 2010 compared to 2009 (from the beginning of the year to end of May, non-fiction and fiction combined.) Thus, it would appear that at this stage, netbooks are not associated with falling demand for books.

Many school libraries spend considerable amounts of staff time maintaining a website. Pathfinders are constructed and reading lists developed, plus many other resources. However, student access to computers will affect their ability to use these resources. Moodle allows site usage reports to be generated. Using moodle reports that measure every click, usage of the library site was compared in weeks 3 to 6 of Term 2, 2009 to 2010. Netbooks increased from 300 in 2009 to 800 in 2010. Library staff also upgraded the moodle site in 2009. Use of the library website increased from 2674 to 3803 'visits.' The figures also show that students stayed longer interacting with the site.

Table 2 Comparison of library website usage from 4 week period in 2009 with 300 netbooks to same period in 2010 with 800 netbooks (All Hallows' School, 2010)

\begin{tabular}{|l|l|l|}
\hline Number of clicks & $27 / 4 / 09-22 / 5 / 09$ & $26 / 5 / 09-21 / 5 / 10$ \\
\hline Guest & 0 & 152 \\
\hline Family & 39 & 51 \\
\hline Library staff & 1152 & 491 \\
\hline Other staff & 177 & 340 \\
\hline Student & 1306 & 2769 \\
\hline Total & 2674 & 3803 \\
\hline
\end{tabular}

Table 3 Comparison of number of different students using the library website in a 4 week period in 2009 with 300 netbooks to same period in 2010 with 800 netbooks (All Hallows' School, 2010)

\begin{tabular}{|l|l|l|}
\hline Number of different students & 2009 & 2010 \\
\hline & 338 & 510 \\
\hline
\end{tabular}

Table 4 Percentage usage of library website in 4 week period in (All Hallows' School, 2010)

\begin{tabular}{|l|l|}
\hline Students Site Visits & 2010 \\
\hline Referencing resources & 4.9 \\
\hline Assignment Pathfinders & 15 \\
\hline Forum & 6.5 \\
\hline
\end{tabular}

(C) 2010 IASL, SLAQ and therein by the authors. Diversity Challenge Resilience: School Libraries in Action Proceedings of the $12^{\text {th }}$ Biennial School Library Association of Queensland, the $39^{\text {th }}$ International Association of School Librarianship Annual Conference incorporating the $14^{\text {th }}$ International Forum on Research in School Librarianship, Brisbane QLD Australia, 27 September - 1 October 2010. 


\begin{tabular}{|l|l|}
\hline Catalogue & 50.7 \\
\hline Reading lists & 2.3 \\
\hline Subscription Databases & 10.4 \\
\hline Other $<30$ & 3 \\
\hline Fun stuff & 3.6 \\
\hline Student Book reviews & 3.6 \\
\hline & 100 \\
\hline
\end{tabular}

These figures show the importance of the catalogue as a 'drawcard' for the library website. The interactive parts of the site were new in 2009, and include the forums, 'fun stuff' and student book reviews, which are now an important part of the site. While these figures are just a hint at the information that could be gleaned from moodle reports, they seem to indicate that if school library website use is to be optimised, then access to PPMs is likely to increase value from online resources, and that students enjoy using interactive resources.

Increased computer access can greatly benefit libraries. Sue Toms (Toms, 2010), from the International School of Tanganyika reported that the impact of netbooks on her library was huge. Use of netbooks outside class has been a huge drawcard for her library, to the extent they have had to roster use by different grades. She has found that on the days students cannot use the netbooks, they have discovered they enjoy the library so much that students read or play games in the other areas. She feels it has helped students see the library as a 'good' place to be. She said the students have to walk past all the display shelves on their way to the netbooks and borrowing has increased $40 \%$ this year.

So far this year at All Hallows' School numbers of students in our library outside class, also appear to be considerably higher, and students with netbooks are very prevalent. There is an increased noise level that seems to be associated with computer usage. The library has opened another space to provide a quieter option.

We have a range of goals for next year in relation to our library moodle site, and the statistics support these initiatives. We are keen to develop short, self-marking, information literacy modules with accompanying quizzes. In NSW, similar online modules are used in relation to the "All My Own Work" program which aims to teach students about the need for referencing, which some schools are already delivering via moodle (NSW Board of Studies, 2007). We will improve our provision of reading lists and promote these with students. The development of other interactive components on the site will also be extended.

\section{Conclusion}

Many libraries have become quasi-computer labs. With netbooks, there is the chance for libraries to regain their role as resource centres, rather than just computer centres. Finally, there are opportunities for libraries to lead in the use of online tools to facilitate information literacy and reading. Devices such as netbooks open up great opportunities for 'continuous' learning, and accessing information and reading, anywhere, anytime. It is up to libraries to take advantage of this access, to further imprint the importance of libraries on our school communities.

For maximum learning value, forget laptop trolleys and shared devices. In our experience, these were labour intensive to manage and they are not as effective as personal devices. The use of a slate with chalk was technology - it was portable. Exercise books and pens are technology - they are personal and portable. Netbooks represent a step forward - personal, portable and multifunctional. Still, the device alone will not improve learning outcomes, or increase information literacy. Teachers and effective teaching practices are the essential the $14^{\text {th }}$ International Forum on Research in School Librarianship, Brisbane QLD Australia, 27 September - 1 October 2010. 
ingredient for success. However, for many educators, the lack of definitive research on the effectiveness of oneto-one programs is irrelevant - they 'know this already...

...indicators of success in a 1-to-1 computing program will appear in classrooms that are differentiated in genuine ways for all students, with teachers who gather and mine just-in-time data. ... Further, teachers, students, and parents use [technology] every day to collaborate about what to do next in their collective pursuit of learning. For them, waiting passively for the results of the big, once-a-year standardized test is not an option. That is why, if asked about the value of using a laptop computer in school, each would struggle to see the relevance of such a question, because computers have become integrated into what they do (Weston and Bain, 2010).

\section{Statement of Originality}

This statement certifies that the paper above is based upon original research undertaken by the author and that the paper was conceived and written by the author(s) alone and has not been published elsewhere. All information and ideas from others is referenced.

\section{References}

All Hallows' School. (2010). Moodle resources from school intranet. Brisbane, Australia: All Hallows' School.

Ash, K. (2010, March 16). Learning benefits seen in laptop initiative. edweek.org. Retrieved June 5, 2010, from http://www.edweek.org/ew/articles/2010/03/18/26laptops.h29.html?tkn=ZUZFvVwjNdpnSaWr6wGV92XETp3 $15 x$ E6UfIk\&cmp=clp-edweek

Bielefeldt, T. (2006). Teaching, learning, and one-to-one computing.International Society for Technology in Education National Educational Computing Conference, San Diego, July 6, 2006: Retrieved June 5, 2010, http://center.uoregon.edu/ISTE/uploads/NECC2006/KEY_19530803/Bielefeldt_UbiCompNECC2006.pdf

Centre for Digital Education. (2008). A complete guide to one-to-one in the K-12 environment. Retrieved June 5, 2010, from http://www.one-to-oneinstitute.org/files/CDE07_Book_MPC_K12.pdf

Dunleavy, M., Dexter, S., \& Heinecke, W. (2007). What added value does a 1:1 student to laptop ratio. edtechcases.info Retrieved June 5, 2010, from: http://edtechcases.info/analysis/DunDexHeinUseCrossCase.pdf

eschoolnews.com. (2009). Study: students want more online learning. Retrieved June 5, 2010, from http://www.eschoolnews.com/2009/07/01/study-students-want-more-online-learning/

Fogel, R. (2010). Lesson learnt and policy implications. Retrieved June 5, 2010, from New Millenium Learners Conference, Intel World Ahead: http://www.bildung.at/nml-conference2010/files/FOGEL.pdf

Intel. (2009). Intel eLearning deployment guide: how to integrate ICT in education for the 21st Century. Retrieved June 5, 2010, from http://download.intel.com/intel/worldahead/pdf/Intel_eLearning_Deployment_Guide_fin.pdf

Intel. (2009). The positive impact of eLearning. Retrieved June 5, 2010, from http://download.intel.com/pressroom/archive/reference/Positive_Benefits_of_eLearning_whitepaper.pdf

(C) 2010 IASL, SLAQ and therein by the authors. Diversity Challenge Resilience: School Libraries in Action Proceedings of the $12^{\text {th }}$ Biennial School Library Association of Queensland, the $39^{\text {th }}$ International Association of School Librarianship Annual Conference incorporating the $14^{\text {th }}$ International Forum on Research in School Librarianship, Brisbane QLD Australia, 27 September - 1 October 2010. 
McKenzie, J. (2008). Getting attention in the laptop classroom. Retrieved June 5, 2010, from http://www.fno.org/nov08/attention.html

NSW Board of Studies. (2007). Up and running:all my own work. Retrieved June 5, 2010, from http://news.boardofstudies.nsw.edu.au/index.cfm/2007/5/14/All-My-Own-Work-Up-and-Running

Pembroke, J. (2009). Teaching the netbook way. Retrieved June 5, 2010, from http://www.intel.com/au/directions/assets/13283_Intel_AllHallows_Case\%20study_2.pdf

Prabhu, M. T. (2008). Report challenges online-learning assumptions. eschoolnews.com . Retrieved June 5, 2010, from: http://www.eschoolnews.com/2008/11/19/report-challenges-online-learning-assumptions/

Saldais, M., \& Easton, M. (2008). oxfordbigideas.com Retrieved June 5, 2010, from: http://www.oxfordbigideas.com/_data/assets/pdf_file/0003/157467/BI_HUM_E.pdf

Silvernail, D. L., \& Gritter, A. K. (2008). Maine's Middle School laptop program: creating better writers. University of Southern Maine. Retrieved June 5, 2010, from:

http://usm.maine.edu/cepare/Impact_on_Student_Writing_Brief.pdf

Spektor-Levy, O., Doron, E., Menashe, K., \& Raviv, D. (2009). Learning with personal laptops in school: benefits and gains, obstacles and constraints. Retrieved June 5, 2010, from http://telempub.openu.ac.i1/users/chais/2010/morning/2_3.pdf

Stansbury, M. (2008). 'Hybrid' courses show promise. eschoolnews.com Retrieved June 5, 2010, from http://www.eschoolnews.com/2008/04/03/hybrid-courses-show-promise/

Stansbury, M. (2010). One-to-one computing programs only as effective as their teachers. eschoolnews.com Retrieved June 5, 2010, from: http://www.eschoolnews.com/2010/02/16/11-programs-only-as-good-as-theirteachers/

State Government of Victoria, Department of Education and Early Childhood Development. (2009). Eduweb Technology for learning: personal, portable and sociable. Retrieved June 5, 2010, fromhttp://www.eduweb.vic.gov.au/edulibrary/public/publ/research/publ/researcharticle_technology_for_learnin g.pdf

Toms, S. (2010). Thinkingoutsidethebox. Retrieved June 5, 2010, from http://www.flickr.com/photos/33137321@N06/4431205272/in/set-72157623616582350/

Weaver, A. (2010). Canoodling with Moodle - school libraries get up close and personal. Access, Journal of the Australian School Library Association, 24 (1).

Weston, M. E., \& Bain, A. (2010). The end of techno-critique : the naked truth about 1:1 laptop initiatives and educational change. escholarship.bc.edu Retrieved June 5, 2010, from:

http://escholarship.bc.edu/cgi/viewcontent.cgi?article=1193\&context=jtla

(C) 2010 IASL, SLAQ and therein by the authors. Diversity Challenge Resilience: School Libraries in Action Proceedings of the $12^{\text {th }}$ Biennial School Library Association of Queensland, the $39^{\text {th }}$ International Association of School Librarianship Annual Conference incorporating the $14^{\text {th }}$ International Forum on Research in School Librarianship, Brisbane QLD Australia, 27 September - 1 October 2010. 
Wikipedia co-contributors. (2010). Blended learning. Retrieved June 5, 2010, from http://en.wikipedia.org/wiki/Blended_learning

Ziptales. (2010). Ziptales. Retrieved June 5, 2010, from http://www.ziptales.com.au/

Zucker, A. A., \& Light, D. (2009). Laptop programs for students. Science , 323 (5910), pp. 82-85.

(C) 2010 IASL, SLAQ and therein by the authors. Diversity Challenge Resilience: School Libraries in Action Proceedings of the $12^{\text {th }}$ Biennial School Library Association of Queensland, the $39^{\text {th }}$ International Association of School Librarianship Annual Conference incorporating the $14^{\text {th }}$ International Forum on Research in School Librarianship, Brisbane QLD Australia, 27 September - 1 October 2010. 